\title{
RETRACTED ARTICLE: Artificial heat waves induce species-specific plastic responses on reproduction of two spider mite predators
}

\author{
A. Walzer ${ }^{1}$ (D) $\cdot$ T. Steiner $^{1} \cdot$ B. Spangl ${ }^{2}$ (D) $\cdot$ E. Koschier ${ }^{1}$ D
}

Received: 19 November 2020 / Revised: 7 October 2021 / Accepted: 15 October 2021 / Published online: 25 November 2021

(c) The Author(s) 2021

The authors have retracted this article as they did not have the necessary permits for the import and experiments on the Neoseiulus womersleyi. All authors agree to this retraction.

The online version of this article contains the full text of the retracted article as Supplementary Information.

Supplementary Information The online version contains supplementary material available at https://doi.org/10.1007/s10340-021-01459-z.

Open Access This article is licensed under a Creative Commons Attribution 4.0 International License, which permits use, sharing, adaptation, distribution and reproduction in any medium or format, as long as you give appropriate credit to the original author(s) and the source, provide a link to the Creative Commons licence, and indicate if changes were made. The images or other third party material in this article are included in the article's Creative Commons licence, unless indicated otherwise in a credit line to the material. If material is not included in the article's Creative Commons licence and your intended use is not permitted by statutory regulation or exceeds the permitted use, you will need to obtain permission directly from the copyright holder. To view a copy of this licence, visit http://creativecommons.org/licenses/by/4.0/.

A. Walzer

andreas.walzer@boku.ac.at

1 Department of Crop Sciences, Institute of Plant Protection, University of Natural Resources and Life Sciences, 1180 Vienna, Austria

2 Department of Landscape, Spatial and Infrastructure Sciences, Institute of Statistics, University of Natural Resources and Life Sciences, 1180 Vienna, Austria 